\title{
Teacher's Experience and Beliefs: Teaching English by Integrating Web-based Learning
}

DOI: https://doi.org/10.47175/rielsj.v1i3.151

\author{
| Desy Nur Fakhomah ${ }^{1, *}$ \\ ${ }^{1,2,3}$ Department of English \\ Education, Sebelas Maret \\ University, Surakarta, \\ Indonesia \\ *dnurfakhomah@gmail.com
}

\begin{abstract}
Abdul Asib² | Dewi Rochsantiningsih ${ }^{3} \mid$
\section{ABSTRACT}

Recently, the science and technology improvement has contributed to the improvement in language teaching and learning. There are many various technologies that can be used for teaching and learning English. One of them is web-based learning. However, not all the teachers know how to integrate technology in their teaching process. This study wants to delve deeper understanding into how an English teacher's beliefs and experience towards web-based learning in English teaching learning process. A narrative inquiry study was conducted towards the participant who has used webbased learning for language teaching and learning at a non-formal school. The teacher's lesson plans and interview were used for collecting the data. The data were coded and analyzed using Thematic Analysis Single Case Study. The result of this study showed that the participant has positive beliefs toward web-based learning for teaching and learning English.

KEYWORDS

Narrative Inquiry; Teacher's beliefs; Teaching English; Web-based Learning
\end{abstract}

\section{INTRODUCTION}

Recently years, the science and technology improvement has contributed to the improvement in language teaching and learning. Language teachers utilize mobile device, computer and internet with their software and facilities for the purpose of teaching and learning activities in the classrooms. One of the technologies that the teacher used is web-based learning.

The research focuses on the teacher's belief and experience towards web-based learning through mobile device in a formal school. It means that a proposition which is accepted as true by the English teachers that guide their personal thought and action to define and understand on web-based learning. The researcher investigates the teacher's beliefs about website in teaching learning English.

The topic of the research is important to be conducted since the importance of the webbased learning usage in this Covid situation. The Education Minister in Indonesia has commanded that the teaching and learning process should be online. The teacher must face a fast change in this condition. However, not all teachers have used website in their institutions in this situation especially in the non-formal school in Indonesia. Therefore, the researcher chose the participant who has taught at non-formal school and used the web-based learning. Thus, the researcher wants to investigate the teacher's beliefs and experience towards web-based learning. Hopefully, this research can become a good topic for discussing in National or International level.

The theories of this research are teacher's belief, and web-based learning. Borg (2009) defined that a belief is a proposition which may be consciously or unconsciously held, is evaluative in that it is accepted as true by the individual, and is therefore imbued with emotive commitment; further, it serves as a guide to thought and behavior. Beliefs help 
teachers to make sense of what they experience in the classroom, they create meaning for teachers. Watson (2006) in Ertmer and Leftwich (2010) found out that teachers' value beliefs with regards to the technology are based on whether or not they think technology can help them achieve the instructional goals they perceive to be most important. Teachers' reasons for using technology in the classroom usually relate to their beliefs that technology can address important teaching and learning needs (Judson, 2006; Zhao\& Frank, 2003). Another expert Richards and Lockhart (1994) provide guide lines for English teachers and researchers for the investigation of teachers' belief which includes beliefs, namely: belief about English, belief about learning, belief about teaching, belief about the program and curriculum, and belief about teaching as profession.

In term of web-based learning, Clark (1996, cited in Henke, 1997) stated that WBL is "individualized instruction delivered over public or private computer network sand displayed by a Web browser". Khan (1997) stated that WBL is World Wide Web which is utilized for a hypermedia-based educational programs and to produce meaningful learning environment. Another definition comes from Relan and Gillami (1997), they defined WBL as by utilizing the attributes and resources from World Wide Web, it can be implemented a repertoire of cognitively oriented instructional strategies with a constructivist and collaborative language learning environment. It can be concluded that Web-based learning is an educational program which utilizes Worlds Wide Web in language learning.

The topic has been examined by some researchers. The first study was conducted by Chamoro, and Rey (2009) entitled Teachers' Beliefs and Integration of Technology in the EFL Class. It examined what teachers believe about the effectiveness of using technology in an English program at university level and how these beliefs affect the use of these types of tools in their classes. The research conducted was a qualitative study and the analysis of data revealed that the use of technology-based activities in the English classroom is twofold: reinforcing already studied topics in class and promoting motivation.

The second study was conducted by Palak and Walls (2009) entitled Teachers' Belief and Technology Practices: A Mixed-methods Approach. This paper is a sequential mixed methods design, the research sought to examine the relationship between teachers' beliefs and their instructional technology practices among technology-using teachers who worked at technology-rich schools to ultimately describe if change in practice toward a studentcentered paradigm occurred. Different from previous researches (Chamoro, and Rey (2009); Palak and Walls (2009)), the context of the study focused on an individual English teacher's beliefs and experience at a non-formal school in Central Java since the participant has used web-based learning for teaching and learning process since 2019. Besides, this study focused on narrative study as the report of the research.

Other studies are investigated related to Web based-learning which entitled Teachers' and Learners' Attitudes toward the Use of Web-based Language Learning (WBLL) conducted by (Nosrati, 2015). The study is concerned with exploring how EFL students and teachers perceive the use of computer technologies, web based language learning and their integration into foreign language teaching and learning. Another study related to web-based learning is entitled Web-Based Teaching and Learning Approach (WBTLA) Usability in Institutions of Higher Learning in Malaysia conducted by Nordin and Alias (2013). With the use of WBTLA emerged problems related to usability in technical, pedagogical and contextual aspects of teaching and learning. In the other hand, this research focused on the use of webbased learning from the Indonesian government to get the novelty and policy gap. That is http://www.setara.kemdikbud.go.id. This website is made specifically for non-formal school in Indonesia since the students do not have daily face to face learning from the beginning. Here are the pictures of the website used by the teacher. 


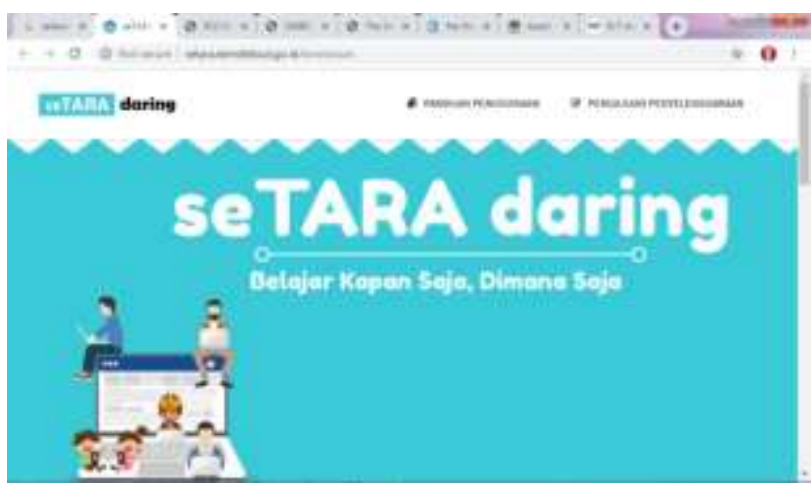

Figure 1. The homepage of the website

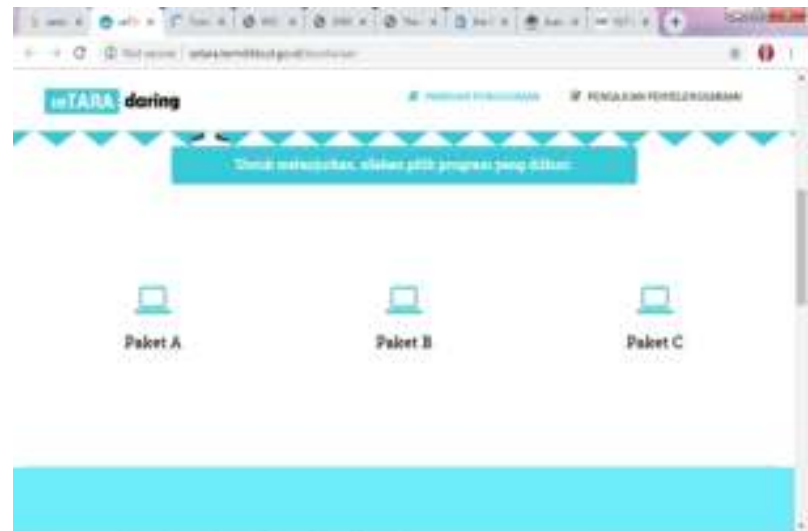

Figure 2. The choices of the package types in the website

Therefore, the researcher tries to describe and analyze the teacher's beliefs and experience towards website in English teaching learning process. Thus, the research that is carried out by the researcher entitled "Teacher's Beliefs and Experience: Teaching English by Integrating Web-based Learning". To sum up, the researcher formulates three main objectives. They are teacher's beliefs and experience about 1) teaching English traditionally, 2 ) web-based learning as profession and 3) teaching English using web-based learning.

\section{RESEARCH METHODS}

This study employed narrative inquiry approach to investigate the teacher's beliefs and experience towards web-based learning. Barkhuizen (2014) stated that narrative research is a research design in which storytelling is used as data or a means for data analysis and findings. In the study, the story which was obtained from participant used as main data.

The participant of this study was selected purposively based on the research objective. The English teacher at a non-formal school in Central Java was selected since the participant had their own experience and used the official website from Education Ministry of Indonesia. At the first time, the teacher only taught English by using traditional method and also some media, such as whiteboard, books, and worksheets. Then, in the middle of 2019, the teacher started to use technology such as google form. The teacher had used the google form for making exercise and homework. In August 2019, the teacher got the training to use the web-based learning from the government. The website is http://www.setara.kemdikbud.go.id. The teacher has used the web-based learning for the English teaching learning process for 1 year. Those are the rationale of choosing an individual participant. Barkhuizen (2014) mentioned that the participant is the main character in any narrative inquiry. The study will contain participant's life experiences 
regarding her beliefs and experience towards web-based learning which was represented as the report.

For obtaining the data, the researchers carried out semi-structured interview and document analysis. The researchers took the data from the participant. The interview design was adopted from the theory of beliefs from Richard and lockhart (1994). There were 20 questions consisted of four aspects of teacher's belief. Then, the researcher recorded and transcribed the interview attentively to gain the verified data.

In this study, the data which have been collected were coded and analyzed using Thematic Analysis Single Case Studies. The model of thematic analysis is proposed by Barkhuinzen et al., (2014) which consists of single case studies and multiple case studies. For this study, the researcher used a single case study to analyze the data from an individual participant. Moreover, Barkhuinzen proposed three main activities in the thematic analysis (Barkhuinzen et al., 2014). Firstly, repeatedly reading of the data. Secondly, coding and categorizing the data extracts and the last recognizing the thematic headings. The process of data analysis was begun by listening cautiously to the recording of the participant's interview. After listening several times, the interview was trascripted. The data were read repeteadly to get deeper understanding. Then the data were analyzed and categorized based on the themes. Furthermore, to get trustworthiness, the researcher also conducted triangulation method. The researcher also got the data by interview and document analysis. It was included in the method triangulation. On the other hand, member checking is a process in which the researcher asked one or more participants to check the accuracy of the account. Thus, the researcher asked the participants after transcribing the interview; whether the transcription of the participants' answers were correct or not.

\section{RESULTS AND DISCUSSIONS}

\section{Beliefs about teaching English traditionally: "I used only the traditional method for teaching English"}

The participant is an English teacher in A Non-Formal School at Karanganyar. The nonformal school is a program which is for getting education equality in Indonesia. She has taught English for 3 years in the school. At the first time of her teaching, she used only traditional method for teaching English, such as from books, whiteboards, etc. She said

"I used books for explaining materials. Besides, I also using whiteboards for explaining more, and if there is no deeper explanation in the book."

She usually taught by explaining the materials from the books. And then she translated for the students because the students sometimes did not understand the text. Then, she explained more about the materials in the whiteboard. And the teacher thought that the teacher as the main centered in the teaching process.

\section{Beliefs about web-based learning as profession: "I joined the training program for integrating technology"}

After almost 2 years, in the 2019, she could join the training program from the government. She joined for several times for getting insight about the teachnology.

"I joined training program for using android in non-formal school and $\mathrm{i}$ also joined dissemination program for using the website 'setara daring'. For example, I was trained for how to upload the material to the website"

Before she joined the training program for integrating technology in their teaching process, she did not know how to use the technology for teaching and learning process. She only used for collecting the students' assessment, making report and making lesson plan. She thought that the training program is very useful for her. She got more insight towards 
technology. Besides, she could use technology in the teaching and learning process. Next, she could use power point and Youtube for teaching English to get students' attention. Thus, she could teach English more properly than she taught using traditional method.

\section{Beliefs toward web-based learning: "I use web-based learning for teaching English"}

After the participant had joined the training for using the website 'setara daring', the participant started to use the web-based learning from setara kemdikbud. The website is http://www.setara.kemdikbud.go.id. In her views, web-based learning is learning process through web which also contains materials, evaluation questions, and assessment. The learning is conducted via online. She said.

"I think web-based learning is learning process through web which also contains materials, evaluation questions, and assessment. The learning is conducted via online."

She usually prepared the material, then she uploaded to the website including the evaluation questions or any exercises which were given to the students. After the students had done the exercises, she gave the asssessment to the students through the web-based learning.

She thought that she was as the teacher as the facilitator when teaching using website. She guided the students, how to open the materials and do the exercise in the web. She started by making lesson plan. The lesson plan was started by explaining the materials, then giving direction to the students to open the website and do the exercise, and giving assessment to the students. She also thought that the web-based learning facilitated her in the teaching and learning process.

"For English teaching learning process, I am as the facilitator for directing the students how to use the web based learning. And web-based learning also facilitate the students and me, such as watching video. The students can directly open the video through application/website. I started the teaching and learning activities by making lesson plan, explaining the material and directing the students to open the web-based learning."

The website is an asynchronous website. This means of communication is in a delayed fashioned where individuals upload and access the materials and do not need to be sitting in front of the mobile device all the time. Since the participant has used the asynchronus website, it cannot be used for teaching speaking directly. Thus, regarding to the participant, the website is appropriated for teaching listening, reading and writing skills.

She told that "I usually use it for teaching listening, reading and writing skills. In my opinion, website is appropriated for teaching listening and writing. For listening, the students can only click the audio and listen. And for writing, the students can write such as main idea".

Besides, she also told that in the past she should prepared the video, downloaded, and showed the video or audio for observing activity. However, now she can only gives the link via web and the students can directly watch the video or listen the audio. It was easy thing for her and she thought that this era is how the teacher use the technology wisely and look for the materials from various sources because there are many materials that the teacher can use for teaching English. Next, the teacher can ask the students to open the materials. She thought that the web-based learning could facilitate her to teach English especially in the new normal era.

The use of web-based learning made the students change. She also told about the change of the students after using web-based learning.

"I saw that the result of the students' marks were increased and also the students become independent in learning and submit the task in the approximate time." 
She told that she usually gave announcement via whatsapp group who has submitted the task and who has not submitted. She thought that the students who had not submit the task would feel not good because they had not finished the task so that they would open the website and do the task.

There are two major objectives of findings that are addressed: teacher's beliefs toward using web-based learning and how the teacher's experience using it. As revealed from an indepth interview with the participant, the teacher had a positive beliefs. Her positive beliefs constructed by beliefs towards teaching English, web-based learning as profession, and webbased learning.

In the term of beliefs towards teaching English, the participant thought that the teaching learning process was still teacher-centered. The teacher should explained all the materials and gave assignments. Saini (2014) proposed that in traditional learning students places a passive role rather than an active one. Mostly, one way communication is possible as all students listen to the teacher. This result is consistent with Gowry (2013) observing the difference between traditional and web-based learning in the health education teaching learning process. The results indicated that knowledge on obstetrical palpation among students in web based group is effective than the traditional group students.

In the term of beliefs towards web-based learning as profession, the participant has postive beliefs that the trainings of how to use web-based learning were really helpful for her. She could not use technology well especially web-based learning from Indonesia Education Ministry. Though, she was given training program for using web-based learning. Thus, She could get more insight and knowledge about web-based learning. Richard proposed that teachers' beliefs about professionalism can be explored through questions such as 1) What kind of training do you think language teachers need?, 2) What kinds of professional development activities best support teaching?, and 3) What kind of support for professional development is available at a school you are familiar with? This result is in line with Cetin (2016) conducting study about the effect of technology training program towards the teahers' view and practice. The findings claimed that if teachers are given educational technology course in their teacher preparation programs, they will more readily implement technology in their teaching. Besides, the participants also had positive views on using computers in their teaching and learning.

Next, in the term of beliefs about web-based learning, the participant showed her positive beliefs that she was as the facilitator by integrating web-based learning. Additionally, the teaching learning process becomes the student-centered since the students also independent and submit the task in the approximate time when the teaching learning process using webbased learning. This result is in line with Kay (2011) conducting study about the effectivesness of web-based learning in Science classrooms. The findings showed that teachers were very positive about the learning benefits, design, and engagement value of WBLTs. Similarly, Pacheco (2005) also stated that from a pedagogical perspective, webbased learning supports the change from the traditional teacher-centered classroom to a learner-centered environment. Learners are encouraged to learn by themselves and are motivated to continue in the growth of their own learning when connected to others.

Thus, the participant beliefs and experiences showed that the web-based learning is better that traditional method in English teaching learning process. Besides, the web-based training program could enhance her professional development especially in using web-based learning for English teaching learning process. As a result, the participant could use web-based learning in the English teaching learning process well. Additionally, she had good views towards web-based learning that it made her easier for teaching English skills such as listening and reading. 


\section{CONCLUSION}

In this study, the writer presented the story of an English teacher who has experience in using the web-based learning for teaching English in the non-formal school in Indonesia. The experience reveals beliefs in the aspects of: First, the beliefs about teaching English by traditional method were the participant believed that the teaching learning process was the teacher-centered. Second, the beliefs about web-based training program were very useful and gave more insight to the participant using web-based learning. Third, beliefs about webbased learning was becoming student-centered. Thus, the study showed that the participant had positive beliefs towards web-based learning and her own experience during teaching by traditional method, getting web-based training, and using web-based learning. However, the study has a limitation. It was the study only reported from an individual teacher. It is better for further research has more participants so that the report of the participants'experience will be more vary. Yet, the study could reported the participant's experience in detailed, from the participant did not know the technology until knowing web-based learning. Besides, the writer suggests the government to give web-basedor any technology training programs for the teachers in order that the teachers in Indonesia can be ready to use technology in teaching and learning process in the future. For further research, the writer gives suggestions for cunducting study about the students' beliefs or views towards using web-based learning.

\section{REFERENCES}

Barkhuinzen, G., Benson, P., \& Chik, A. (2014). Narrative Inquiry in Language Teaching and Learning Research. New york: Routledge.

Borg, Michaela. (2001). Teachers beliefs. ELT Journal, 55 (2): 186-188.

Cetin, Nagihan İmer. (2016). Effects of a Teacher Professional Development Program on Science Teachers' Views about Using Computers in Teaching and Learning. International Journal Of Environmental \& Science Education 2016, VOL. 11, NO. 15. Gazi Üniversitesi, Ankara, Turkey.

Chamoro, Martha Gracia and Rey, Lourdes. (2009). Teachers' Beliefs and Integration of Technology in the EFL Class. Colombian Journal for Teachers of English. Retrieved from https://files.eric.ed.gov/fulltext/EJ1128086.pdf

Ertmer, P. A., \& Ottenbreit-leftwich, A. T. (2010). Teacher Knowledge Confidence And Beliefs. Journal of Research on Technology in Education, 42(3), 255-284.

Gowri, P.Mangala, Minolin, Mary, and Thenmozhi. (2013). Web based Vs traditional: A comparison of two instructional methods to teach obstetrical palpation for antenatal mothers among B.Sc(N) II year students. IOSR Journal of Research \& Method in Education (IOSR-JRME) e-ISSN: 2320-7388, Volume 3, Issue 4 (Sep. -Oct. 2013), PP 41-44. Retrieved from: http://iosrjournals.org/iosr-jrme/papers/Vol-3\%20Issue4/G0344144.pdf?id=7370

Henke, H. (2003). Evaluating Web-based Instruction Design. Retrieved March 4, 2005 from the World Wide Web: http://scis.nova.edu/ henkeh/story 1.html

Judson, E. (2006). How teachers integrate technology and their beliefs about learning: Is there a connection?. Journal of Technology and Teacher Education, 14.

Kay, Robin. (2011). Examining the Effectiveness of Web-Based Learning Tools in Middle and Secondary School Science Classrooms. Inter-disciplinary Journal of E-Learning and Learning Objects Volume 7, 2011. Downloaded from: http://www.ijello.org/Volume7/IJELLOv7p359-374Kay781.pdf

Khan, B. H. (Ed.). (1997). Web-based instruction. Englewood Cliffs, NJ: Educational Technology Publications. 
Nordin, Abu Bakar and Alias, Norlidah.(2013). Web-Based Teaching and Learning Approach (WBTLA) Usability In Institutions Of Higher Learning In Malaysia. The Malaysian Online Journal of Educational Technology Volume 1, Issue2. Downloaded from: https://files.eric.ed.gov/fulltext/EJ1086353.pdf

Nosrati, Vahede.(2015). Teachers' and Learners' Attitudes toward the Use of Web-based Language Learning (WBLL) . Journal of Applied Linguistics and Language Research Volume 2, Issue 8, pp. 1-12 Available online at www.jallr.ir ISSN: 2376-760X.

Pacheco, Allen Quesada (2005). Web-Based Learning (WBL): A Challenge For Foreign Language Teachers. Revista Electrónica "Actualidades Investigativas en Educación", 5(2),1-25.(fecha de Consulta 5 de Diciembre de 2020]. ISSN: . Disponible en: https://www.redalyc.org/articulo.oa?id=447/44750210

Palak, D., \& Walls, R. T. (2009). Teachers' Beliefs and Technology Practices: A MixedMethods Approach. Journal of Research on Technology in Education, 41, 417-441. Downloaded from :http://dx.doi.org/10.1080/15391523.2009.10782537

Relan, B. \& Gillami, A. (1997). Incorporating Interactivity And Multimedia Into WebBased Instruction. In B.H. Khan (Ed.), Web-Based Instruction (pp.231-237). Englewood Cliffs, NJ: Educational

Richards, Jack C. and Lockhart, Charles (1994). Reflective teaching in second language classrooms. Cambridge: Cambridge University Press

Saini, Kavita, Wahid, Abdul, and Purohit, G N. (2014). Traditional Learning versus Web Based Learning: Performance Analysis. International Journal of Computer Science and Information Technologies, Vol. 5.

Zhao, Y., and Frank, K. A. (2003). Factors affecting technology uses in schools: An ecological perspective. American Educational Research Journal, 40. 